\title{
White spot syndrome virus infection in cultured Penaeus vannamei (Boone) in Ecuador with emphasis on histopathology and ultrastructure
}

\author{
J Rodríguez ${ }^{1}$, B Bayot ${ }^{1}$, Y Amano ${ }^{2}$, F Panchana ${ }^{1}$, I de Blas ${ }^{3}$, V Alday and J Calderón ${ }^{1}$ \\ 1 Fundación CENAIM-ESPOL, Guayaquil, Ecuador \\ 2 Instituto Nacional de Higiene, Leopoldo Izquieta Pérez, Guayaquil, Ecuador \\ 3 Facultad de Veterinaria, Universidad de Zaragoza, Zaragoza, Spain \\ 4 Centro de Servicios para la Acuacultura, Guayaquil, Ecuador
}

\begin{abstract}
Mortalities of cultured shrimp, Penaeus vannamei (Boone), induced by white spot syndrome virus (WSSV) have occurred in Ecuador since May 1999. Three epidemiological surveys in Ecuadorian farms were carried out and showed an apparent association between lower temperature and increased mortality rates in commercial ponds. Infected animals showed a reddish discolouration and lethargy and occasionally, white spots in the exoskeleton. Histopathological studies revealed that infected cells presented nuclear hypertrophy with eosinophilic to basophilic inclusions. In some cases, two other pathologies were observed: (a) lymphoid organ spheroids and (b) cells with pyknotic and karyorrhectic nuclei in the lymphoid organ, haematopoietic tissue, connective tissue, heart and antennal gland. Occasionally pyknotic cells were encapsulated without apparent injury to the adjacent tissue and without melanization. Transmission electron microscopy showed the presence of WSSV particles in the cytoplasm of cells with pyknotic nuclei in the stomach hypodermis. Viral structure and morphogenesis agreed with previous descriptions by other authors in WSSV-infected shrimp. Occasionally, two nucleocapsids within one envelope were present amongst single enveloped nucleocapsids. A long rod-shaped structure that could reach $2.4 \mu \mathrm{m}$ in
\end{abstract}

Correspondence Dr Jenny Rodríguez, Fundación CENAIM-ESPOL, PO Box (0901) 4519, Guayaquil, Ecuador (e-mail: jrodrigu@cenaim.espol.edu.ec) length was present in the nuclei of some infected cells.

Keywords: Ecuador, epidemiology, histopathology, Penaeus vannamei, ultrastructure, white spot syndrome virus.

\section{Introduction}

White spot syndrome virus (WSSV) infection is the most important disease affecting cultured shrimp today (Lightner 1996; Flegel, Boonyaratpalin \& Withyachumnarmkul 1997). Its negative effects have led to high mortality in different species of penaeid shrimp including all those now cultured (see e.g. Inouye, Miwa, Oseko, Nakano, Kimura, Momoyama \& Hiraoka 1994; Chou, Huang, Wang, Chiang \& Lo 1995; Wongteerasupaya, Vickers, Sriurairatana, Nash, Akarajamorn, Boonsaeng, Panyim, Tassanakajon, Withyachumnarnkul \& Flegel 1995; Lightner 1996; Zhan, Wang, Fryer, Yu, Fukuda \& Meng 1998; Wang, Hassan, Shariff, Zamri \& Chen 1999b). After the first reports of WSSV in Central America in early 1999 (Jory \& Dixon 1999), the disease was first detected in Ecuador in May 1999 and was associated with massive mortalities in some farms (Calderón, Bayot, Betancourt \& Alday de Graindorge 1999). In 1998, the country exported approximately 115000 tonnes of pond-cultured shrimp, mostly reared under semi-intensive conditions. In 2000, exports dropped to 38000 tonnes (Cámara Nacional de Acuacultura 2001).

In this study, we report epidemiological aspects of WSSV outbreaks in cultured Penaeus vannamei 
(Boone) related to seasonal changes in Ecuador. The Ecuadorian coastal climate is highly influenced by the oceanographic conditions of the Pacific Ocean. In normal circumstances the wet/warm season occurs from January to April and the dry/ cold season from June to November. May and December are considered as seasonal transition months. In addition, two climatological events affect the temperature of the Pacific Ocean. 'El niño', which is characterized by warmer surface temperatures (positive anomalies), and 'La niña', characterized by colder surface temperatures (negative anomalies). This report also describes the histopathology of WSSV naturally infected P. vannamei, including survivors, and ultrastructure of the virus.

\section{Materials and methods}

\section{Surveys and sampling}

A total of 589 shrimps were sampled using a cast net in 128 ponds from 77 farms located in the four coastal provinces of Ecuador (Esmeraldas, Manabí, Guayas and El Oro). During the first survey (JuneJuly 1999, dry/cold season) 205 shrimps were collected. The second survey (232 shrimps) was also carried out in the dry/cold season (SeptemberOctober 1999). The third survey (152 shrimps) was carried out in the wet/warm season (April 2000).

\section{Histopathology}

Davidson's AFA (alcohol, formalin, glacial acetic acid) fixative was used to preserve samples for histopathology. Shrimp tissue was processed according to the procedures outlined by Bell \& Lightner (1988). Sections were cut at $5 \mu \mathrm{m}$ and stained with Mayer Bennet haematoxylin and eosin ( $\mathrm{H} \& \mathrm{E})$. The tissues were examined for histopathological changes.

\section{Ultrastructural studies}

Animals sampled for transmission electron microscopy (TEM) were dissected in the field and the tissues fixed in $4{ }^{\circ} \mathrm{C} 3 \%$ glutaraldehyde/ $\mathrm{Na}$ cacodylate $100 \mathrm{~mm} / \mathrm{NaCl} 175 \mathrm{~mm}$. Tissues were postfixed in $1 \%$ osmium tetroxide $\left(\mathrm{OsO}_{4}\right)$ in $100 \mathrm{~mm}$ sodium cacodylate buffer for $1 \mathrm{~h}$, further processed and embedded in Spurr's (TM) resin. Sections were cut in a Reichert Ultracut OMU3 microtome (Leica, Germany) at $100 \mathrm{~nm}$ thickness, stained with uranyl acetate $/ 70 \%$ methanol and lead citrate and examined with a JEOL 1010 transmission electron microscope (JEOL, Japan) at $80 \mathrm{kV}$.

\section{Statistical and epidemiological analysis}

Data were analysed with a chi-square test at a 0.05 level of significance. The odds ratio, which measures the strength of the association between disease and exposure to a risk factor was estimated at the $95 \%$ level of confidence. It is calculated as the prevalence in an exposed group divided by the prevalence in a non-exposed group (Thrusfield 1995).

\section{Results}

White spot outbreaks started in June 1999 and spread over the four Ecuadorian coastal provinces during the second half of 1999 . WSSV as the causal agent was confirmed by nested PCR and histology (Calderón et al. 1999). The outbreaks usually occurred 30-40 days post-stocking of the pond (in Ecuador larvae are usually stocked as postlarva 10-20). Mortality ranged from 60 to $95 \%$ within 5-8 days of detection of the clinical signs.

Incidence in cultured shrimp appeared to increase during the dry/cold season. During April 2000, when the wet/warm season was at its peak, the prevalence of infected animals in the samples decreased compared with September-October 1999 (Table 1$)$. A significant difference $(P<0.001)$ was detected in the prevalence of WSSV between the three surveys (Table 2). When the surveys are studied in pairs, there was a significant difference $(P<0.05)$ in all cases, but there was no difference when the grouped data between both surveys in the dry/cold season (surveys $1+2$ ) and the surveys carried out in the wet/warm season (survey 3) were compared. A significant difference $(P<0.001)$ was detected between both surveys in the dry/cold season. In survey 2 , the prevalence was greater than in survey 1 , which indicates that the disease was spreading.

When the odds ratios were calculated (Table 2) results were similar among surveys. Risk of infection during survey 2 was significantly higher than in surveys 1 and 3 , and also survey 3 was a risk factor compared with survey 1 . 
Table 1 Sea surface temperatures and the prevalence of WSSV in cultured Penaeus vannamei obtained from epidemiological surveys conducted in the four coastal provinces (Esmeraldas, Manabí, Guayas and El Oro) of Ecuador, during different seasons

\begin{tabular}{|c|c|c|c|c|c|c|c|c|}
\hline Survey & Date & Season & Temperature $\left({ }^{\circ} \mathrm{C}\right)^{\mathrm{a}}$ & $\begin{array}{l}\text { Temperature } \\
\text { anomalies }\left({ }^{\circ} \mathrm{C}\right)^{\mathrm{a}}\end{array}$ & $n$ & $\begin{array}{l}\text { WSSV } \\
\text { negative }\end{array}$ & $\begin{array}{l}\text { WSSV } \\
\text { positive }\end{array}$ & $\begin{array}{l}\% \\
\text { prevalence }\end{array}$ \\
\hline Survey 1 & June-July 1999 & Dry/cold & $21.83,20.44$ & $-0.85,-1.14$ & 205 & 185 & 20 & 9.76 \\
\hline Survey 2 & September-October 1999 & Dry/cold & $19.75,19.23$ & $-0.89,-1.09$ & 232 & 135 & 97 & 41.81 \\
\hline Survey 3 & April 2000 & Wet/warm & 25.64 & -0.88 & 152 & 123 & 29 & 19.07 \\
\hline
\end{tabular}

${ }^{a}$ Sea surface temperature (SST) and anomalies (variations of seasonal averages) of SST for 'El niño $1+2$ ' region (oceanic region located between the western coast of South America and $90^{\circ} \mathrm{W}$ and from $0^{\circ}$ to $10^{\circ} \mathrm{S}$ ). The values correspond to the respective monthly average for each case.

Table 2 Chi-square $\left(\chi^{2}\right)$ and odds ratio (OR) values determined from three epidemiological surveys conducted in the four coastal provinces (Esmeraldas, Manabí, Guayas and El Oro) of Ecuador during different seasons

\begin{tabular}{|c|c|c|c|c|c|c|c|}
\hline \multirow[b]{2}{*}{ Surveys } & \multirow[b]{2}{*}{$\begin{array}{l}\text { Risk } \\
\text { factor }\end{array}$} & \multicolumn{3}{|l|}{$\chi^{2}$} & \multicolumn{3}{|l|}{ OR } \\
\hline & & Value & d.f. & $P$ & Value & $\begin{array}{l}95 \% \\
\text { Lower } \\
\text { limit }\end{array}$ & $\begin{array}{l}95 \% \\
\text { Upper } \\
\text { limit }\end{array}$ \\
\hline $1,2,3$ & - & 63.561 & 2 & 0.000 & - & - & - \\
\hline 1,2 & 2 & 57.037 & 1 & 0.000 & 6.646 & 4.063 & 10.870 \\
\hline 1,3 & 3 & 6.406 & 1 & 0.011 & 2.181 & 1.191 & 3.992 \\
\hline 2,3 & 2 & 21.524 & 1 & 0.000 & 3.048 & 1.902 & 4.883 \\
\hline $1+2,3$ & $1+2$ & 3.581 & 1 & 0.058 & 1.551 & 0.984 & 2.444 \\
\hline
\end{tabular}

\section{Histopathology and ultrastructure}

In ponds undergoing a disease outbreak, animals reduced food intake or stopped feeding completely. White spots in the infected shrimp were small and mostly located on the inside surface of the cephalothorax. These spots were not always present, but a reddish body and pinkish colouration of the haemolymph were common in moribund animals, which also presented a general weakness and lethargy.

The histopathology of infected cells was characterized by nuclear hypertrophy with eosinophilic (Cowdry A inclusion) to basophilic inclusions. Several tissues were infected, mainly the cuticular epithelium, the stomach cuticular epithelium, connective tissue, antennal gland, gills, heart and haematopoietic tissue (Figs $1 \& 2$ ). In the lymphoid organ, in addition to the presence of infected cells with inclusion bodies, the presence of spheroids [lymphoid organ spheroids (LOS)] was observed (Fig. 3). In some instances, no cells infected with WSSV were observed in the lymphoid organ and only LOS were present in this tissue, while other tissues of the same specimen were infected. Other pathologies affecting the animals, which had severe infections of WSSV, were the presence of light to severe pyknosis and karyorrhexis. The tissues affected were the lymphoid organ presenting a loss of structure (in the most severe cases) (Fig. 4), the spongy connective tissue beneath the stomach cuticular epithelium (Fig. 5), haematopoietic tissue (to much lesser degree than in the lymphoid organ and without loss of organ structure), heart and antennal gland. Encapsulation of cells with pyknotic nuclei was observed in some infected animals. The encapsulation was not accompanied by melanization and the adjacent tissues did not show lesions that could be attributed to inflammatory foci (Fig. 6). This condition was more evident in the spongy connective tissue basal to the stomach cuticular epithelium. Animals examined that presented pyknosis and karyorrhexis were always severely infected with WSSV but no signs of an infection by Taura syndrome virus (TSV) were observed. TEM examination of cells of the stomach cuticular epithelium with pyknotic nuclei showed the presence of WSSV viral particles in the cytoplasm (Fig. 7). The pyknotic nuclei showed chromatin condensation at the nuclear membrane or a complete condensation of the nucleus. The cytoplasm was condensed and vacuolated, while the mitochondria remained relatively intact (Fig. 7).

Transmission electron microscopy of infected lymphoid organ cells showed hypertrophied nuclei with marginated chromatin and the presence of rod-shaped enveloped virions. The virions were present in a paracrystalline arrangement or scattered in the nuclei (Fig. 8). The virions were from 245 to $308 \mathrm{~nm}$ in length and $98-124 \mathrm{~nm}$ in width. The nucleocapsids ranged from 183 to $262 \mathrm{~nm}$ in length to 60-95 nm in width (Fig. 8). The presence of two nucleocapsids within one envelope was occasionally observed (Fig. 8). The virus envelope was 8-9 nm thick and trilaminar, consisting of two electron opaque layers separated by an electron lucent layer.

A membrane profile consisting of a series of vesicles joined together was present at the early stage of virion development and empty capsids inside these vesicles had asymmetric ends (Fig. 9). Partially 

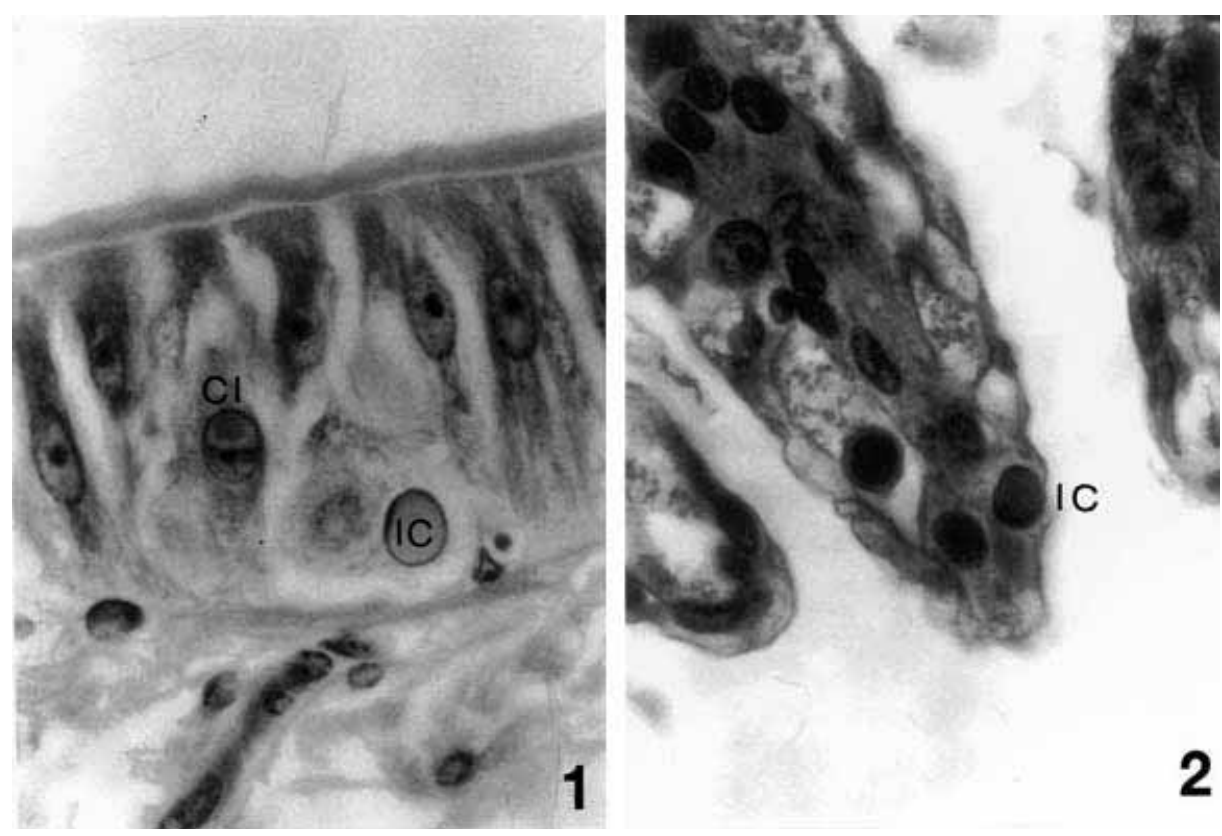

Figure 1 Tissues of Penaeus vannamei infected with white spot syndrome virus (WSSV). Stomach cuticular epithelium showing hypertrophied nucleus and viral inclusion (IC). Note an eosinophilic Cowdry Type A inclusion (CI) (H \& E, ×1000).

Figure 2 Tissues of Penaeus vannamei infected with white spot syndrome virus (WSSV). Hypertrophied nucleus and viral inclusion (IC) in gill tissue $(\mathrm{H} \& \mathrm{E}, \times 1000)$.

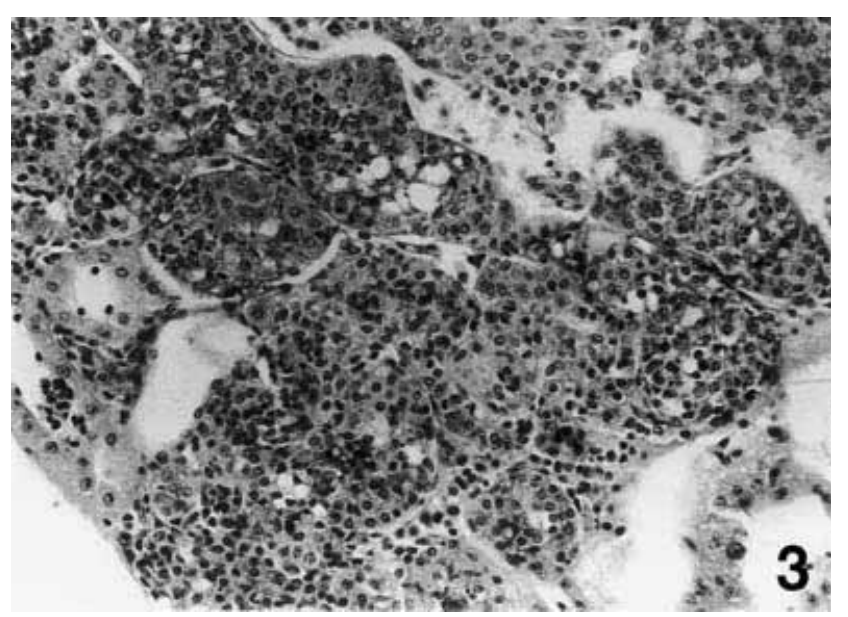

Figure 3 Lymphoid organ of Penaeus vannamei infected with WSSV, showing lymphoid organ spheroids $(\mathrm{H} \& \mathrm{E}, \times 1000)$. enveloped empty capsids were present singly or appeared surrounded by the same envelope (Fig. 10), but with an open end. These were 100-188 nm long and 62-64 nm wide. Single enveloped empty capsids presented segmentation, but this was not clearly evident in all cases as the segmentation was only slightly electron dense (Fig. 10). An electron dense central filament was present in some enveloped capsids (Fig. 11), and these developing capsids were longer and narrower than fully developed virions.
A long rod-shaped structure (LRS) was present in the nucleus of some infected cells alongside fully developed virions (Fig. 8). The LRS reached $2.4 \mu \mathrm{m}$ in length by $50 \mathrm{~nm}$ in width. Along the longitudinal axis of the whole structure an electron lucent core was present which averaged 13-17 nm. Electron dense striations were regularly present in the LRS, however, these striations did not appear to cross the electron lucent core.

Presumptive early stage LRS were made up of numerous repeating subunits but without 

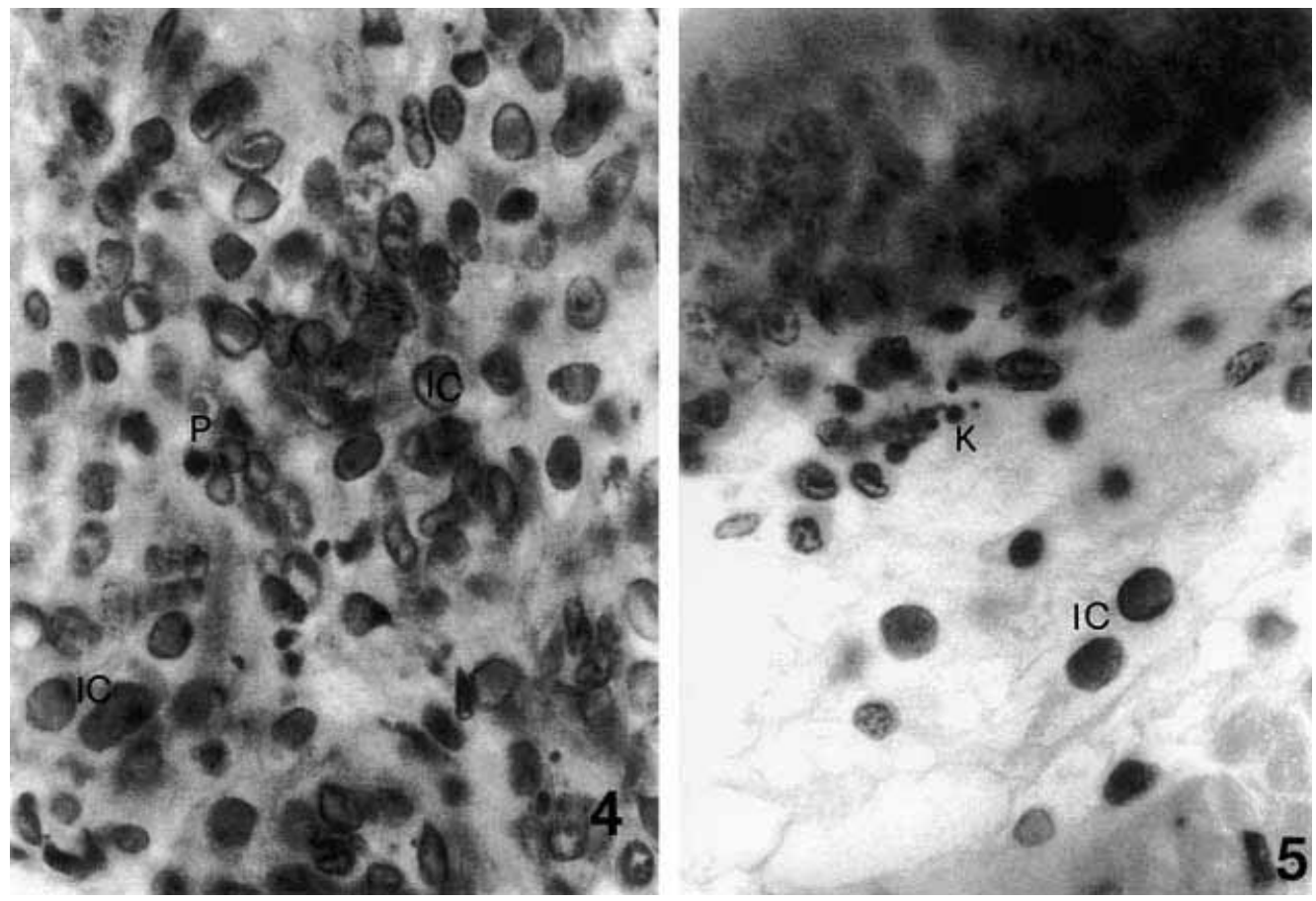

Figure 4 Pyknosis $(\mathrm{P})$ and karyorrhexis $(\mathrm{K})$ in the lymphoid organ of Penaeus vannamei infected with WSSV. Hypertrophied nuclei (IC). (H \& E, $\times 1000)$.

Figure 5 Pyknosis $(\mathrm{P})$ and karyorrhexis $(\mathrm{K})$ in the connective tissue beneath stomach epithelium of Penaeus vannamei infected with WSSV. Hypertrophied nuclei (IC). (H \& E, ×1000).

Figure 6 Cell nucleus with pyknotic encapsulated in the subcuticular connective tissue of the stomach epithelium of Penaeus vannamei $(\star)$. Hypertrophied nuclei (IC).

separation between longitudinal sections (Fig. 12). Differentiation of the longitudinal sections was evident in the nuclei of some cells (Fig. 13) and well-defined electron dense and electron lucent longitudinal sections were also seen in LRS (Fig. 14). The subunits of the well-developed LRS were longitudinally and transversely separated.

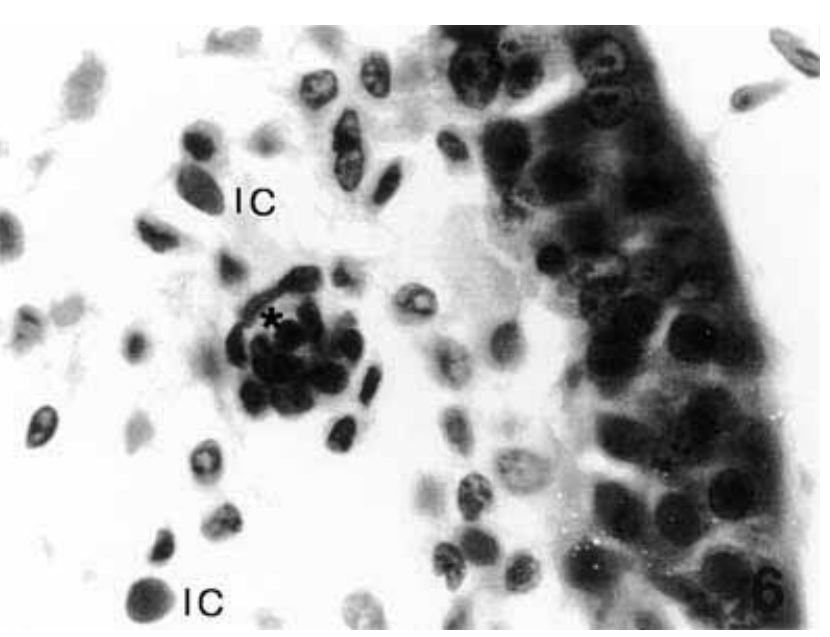

Smaller LRS approximately $50 \mathrm{~nm}$ wide, but of different lengths were also seen (Figs 8 \& 15).

\section{Discussion}

The data presented in this study suggest an association between the prevalence of WSSV and
(C) 2003

Blackwell Publishing Ltd 


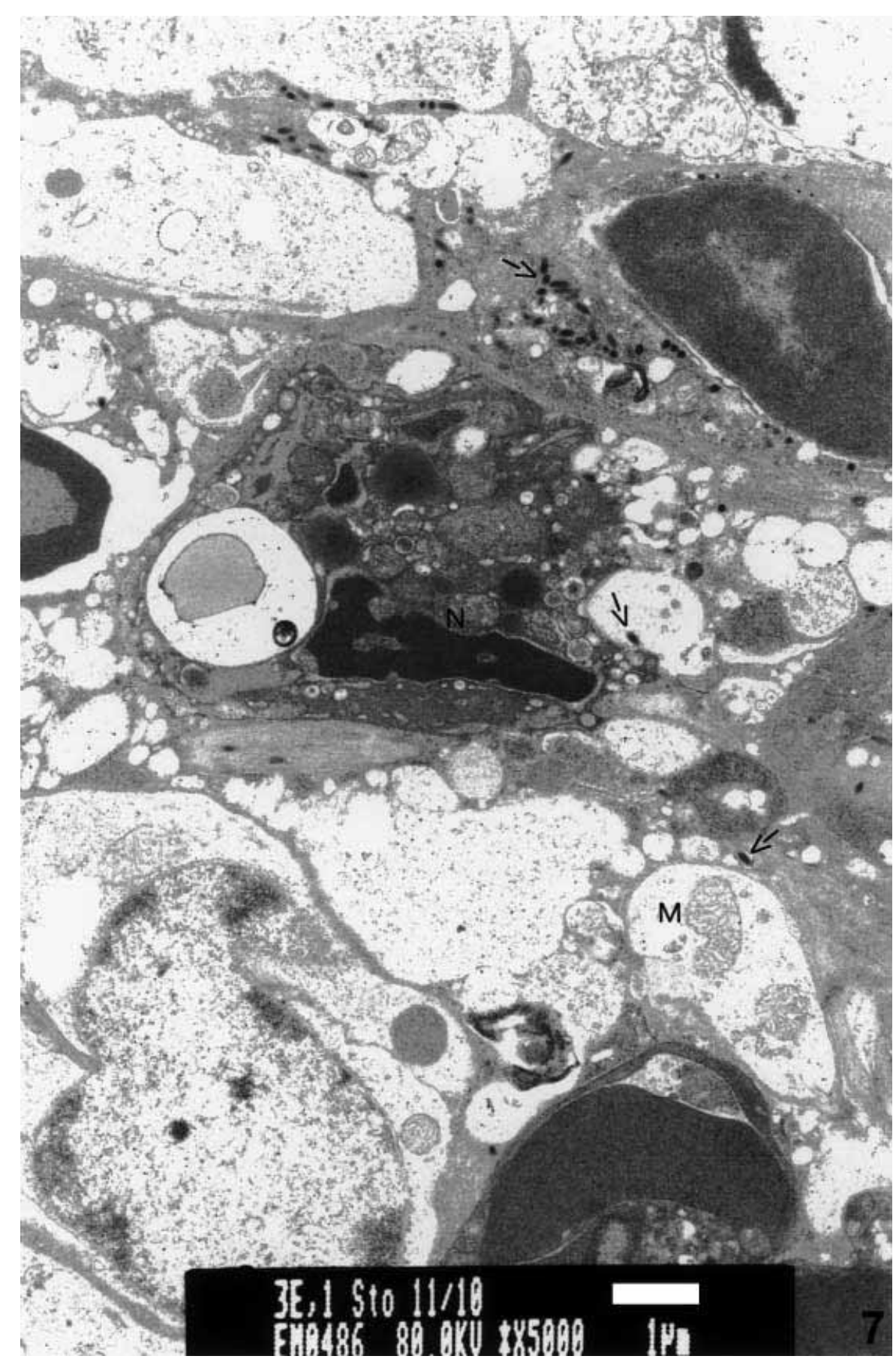

Figure 7 Electron micrograph of the stomach epithelium of Penaeus vannamei infected with WSSV. Condensed nucleus (N), mitochondrion $(\mathrm{M})$, virus particles in the cytoplasm (arrows) (bar $=1 \mu \mathrm{m})$.

mainly dry/cold climatological conditions in this geographical area. The first epidemiological survey was carried out at the beginning of the dry/cold season in June-July 1999. During June and July water temperature is normally cold, but in this year cold (negative) anomalies of -0.85 and $-1.14{ }^{\circ} \mathrm{C}$ below seasonal average, respectively, were detected. The second survey was during the height of the dry/ cold season in September-October 1999, when the water temperature was colder than in June-July and 


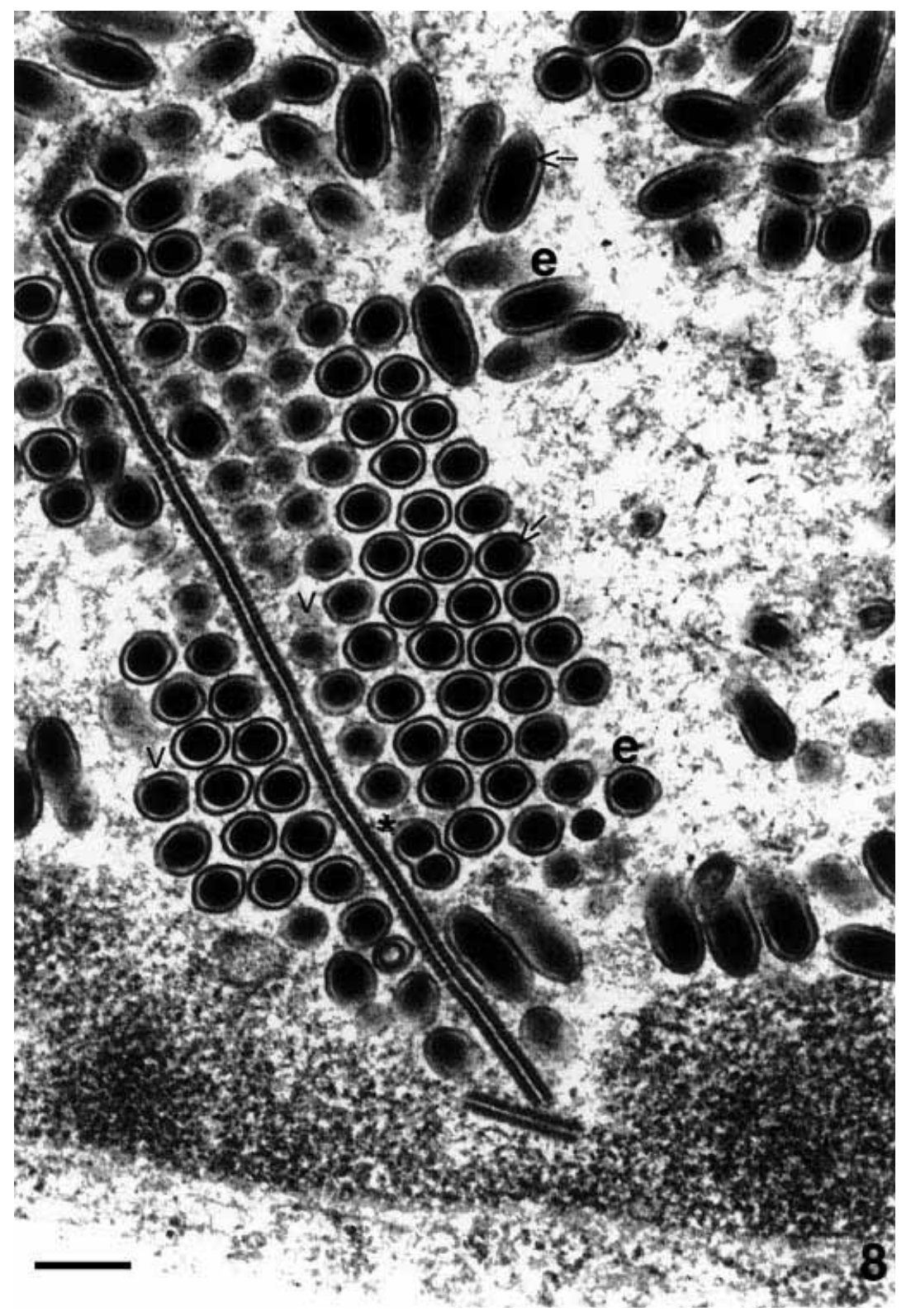

Figure 8 Electron micrograph of a cell nucleus of the lymphoid organ of Penaeus vannamei infected with WSSV. Virus particles in paracrystalline arrangement $(\mathrm{V})$, nucleocapsid (arrow), envelope (e), two nucleocapsids within one envelope $(\star)($ bar $=200 \mathrm{~nm})$.

negative anomalies persisted $\left(-0.89\right.$ and $\left.-1.09{ }^{\circ} \mathrm{C}\right)$. Thus, at these times water temperatures were even lower than the normal cold conditions because of the 'La niña' event. This could be a cause of the higher prevalence of WSSV during the second survey when compared with the other surveys. The odds ratios between survey 1 and survey 2 and between survey 2 and survey 3, show a higher risk of the disease during the second survey. In April 2000 (survey 3 ), when the wet/warm season is normally fully developed, the prevalence of WSSV decreased compared with survey 2 . The water temperature anomaly remained negative $\left(-0.88^{\circ} \mathrm{C}\right)$ at this time because of the continuing 'La niña' event. The odds ratio showed that there was a higher risk of disease development in the third survey than in the first one. The increase in WSSV prevalence between survey 1 and survey 2 might be a consequence of the expanding distribution of the virus as the epizootic spread and/or the effect of the drop in water
(C) 2003

Blackwell Publishing Ltd 


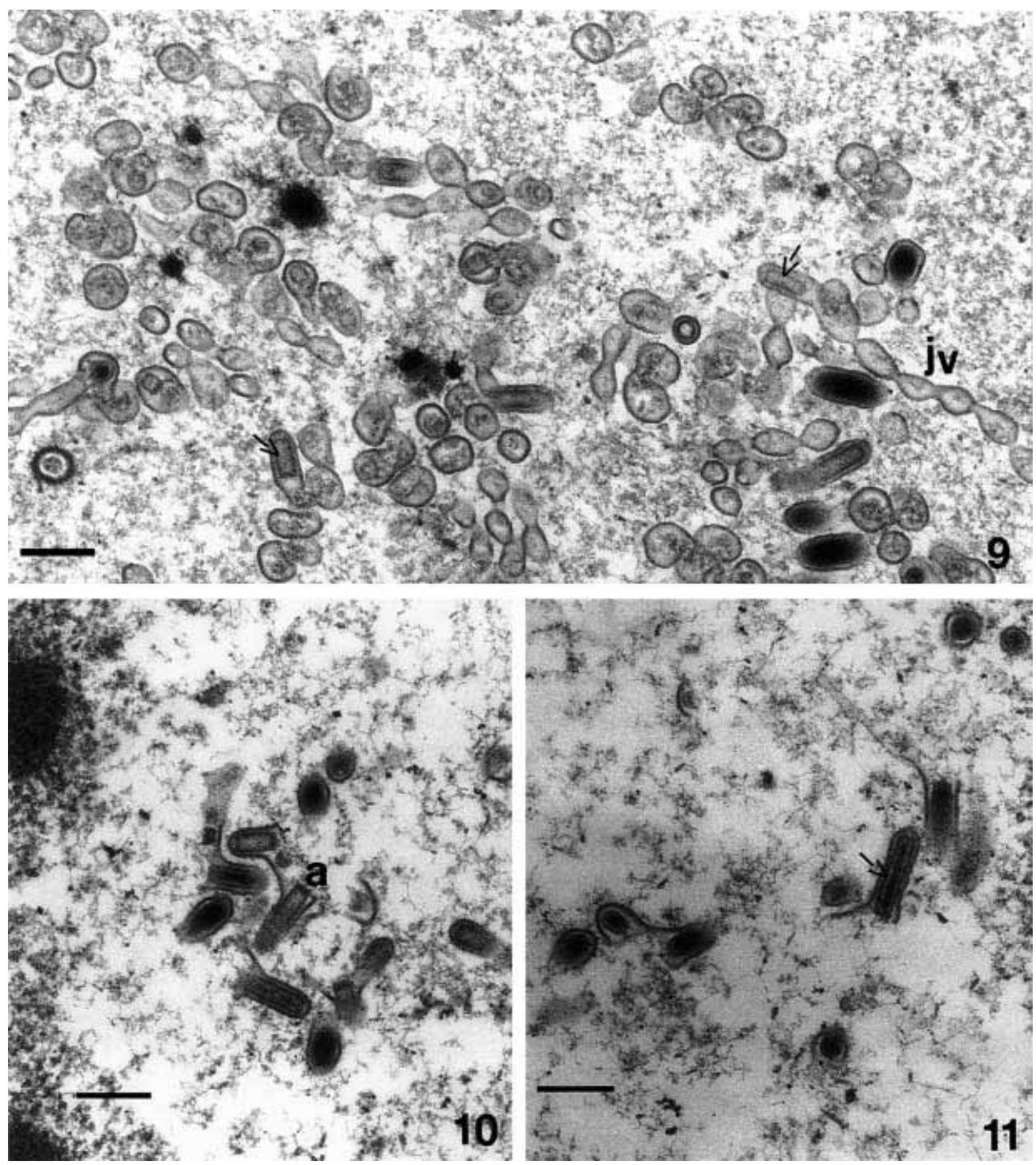

Figure 9 Electron micrograph of the lymphoid organ of Penaeus vannamei infected with WSSV. Nucleus at early stage of viral infection; empty capsids (arrow), joined vesicles (jv) (bar $=200 \mathrm{~nm}$ ).

Figure 10 Electron micrograph of the lymphoid organ of Penaeus vannamei infected with WSSV. Empty capsid with asymmetric ends (a) $($ bar $=200 \mathrm{~nm})$.

Figure 11 Electron micrograph of the lymphoid organ of Penaeus vannamei infected with WSSV. Nucleocapsid with central filament (arrow) (bar $=200 \mathrm{~nm})$.

temperature as the cold season developed. This effect would be exacerbated by the 'La niña' event. The effect of temperature could explain the decrease in prevalence in survey 3 during the warm season, when temperatures were almost $6{ }^{\circ} \mathrm{C}$ higher than in survey 2 , despite the continuing 'La niña' event. The higher prevalence and odds ratio of WSSV in survey 3 compared with survey 1 might be due to the spread of the virus. Survey 1 was conducted during the early phase of the WSSV epizootic. The continued occurrence of the 'La niña' event lowered the average temperatures at the time of survey 3 which may have reduced the magnitude of the temperature effect on the virus. Our results suggest that the dry/cold season is an important risk factor in the occurrence of WSSV in Ecuador and that the risk increases with time over this season.

Further research is needed to determine the mechanisms and effects of environmental stress in triggering a disease outbreak in shrimp ponds. 

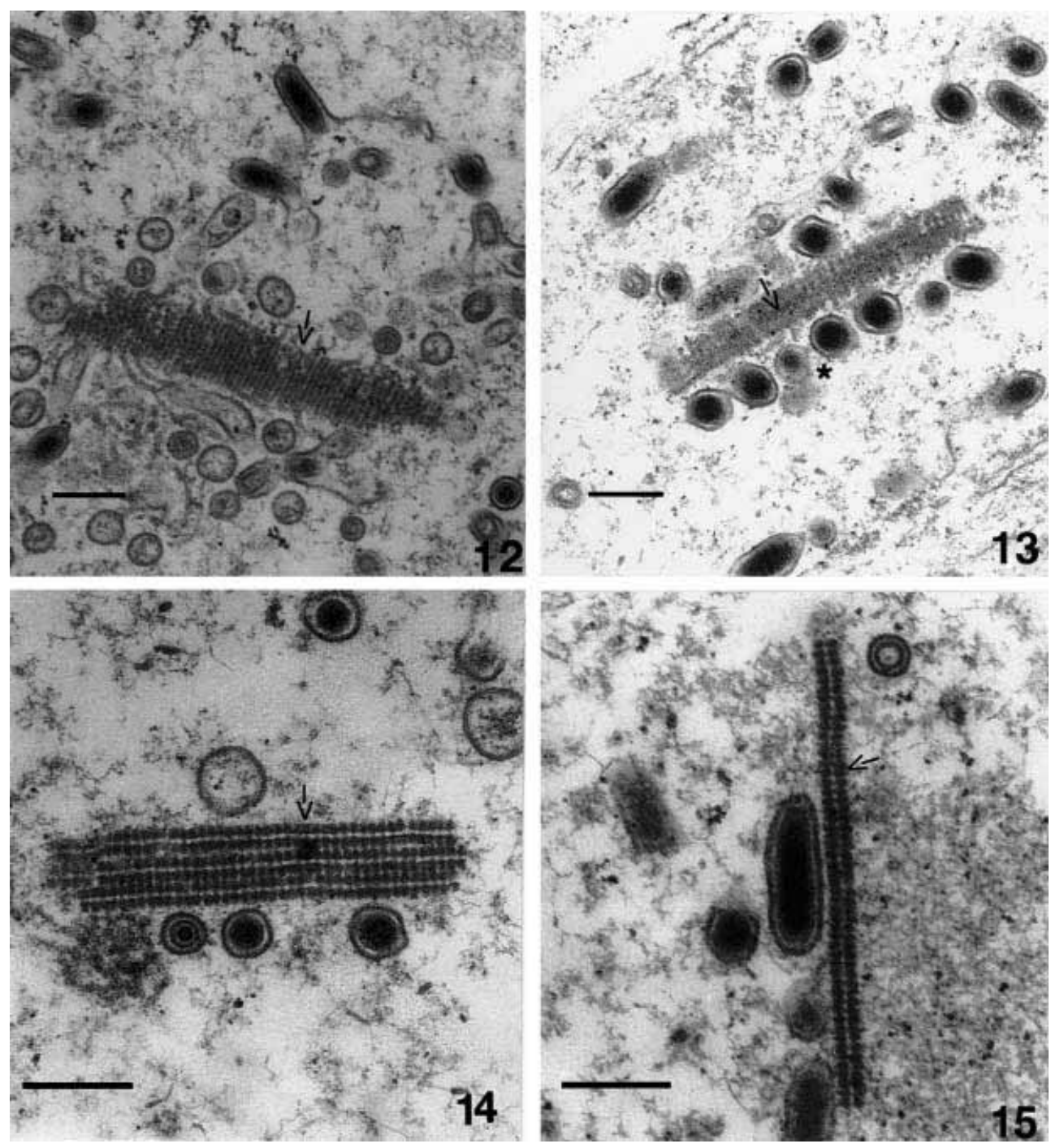

Figure 12 Electron micrograph of long rod-shaped structure (LRS) in the nucleus of WSSV-infected cell. Presumptive early stage of LRS formation. LRS with repeating subunits without separation in long sections (arrow) (bar $=200 \mathrm{~nm}$ ).

Figure 13 Electron micrograph of long rod-shaped structure (LRS) in the nucleus of WSSV-infected cell. LRS with slight differentiation between longitudinal sections (arrow); note virions in cross section arranged next to LRS $(\star)(b a r=200 \mathrm{~nm})$.

Figure 14 Electron micrograph of long rod-shaped structure (LRS) in the nucleus of WSSV-infected cell. LRS with three repeating units (arrow) (bar $=200 \mathrm{~nm}$ ).

Figure 15 Electron micrograph of long rod-shaped structure (LRS) in the nucleus of WSSV-infected cell. LRS consisting of 1 subunit (arrow) $($ bar $=200 \mathrm{~nm})$.

Outbreaks have been empirically associated with environmental changes (Flegel et al. 1997), or water temperature (Zhan et al. 1998; Jiménez, Barniol, de Barniol \& Machuca 2000). In this study there was an apparent association between low temperatures and increased mortality rates in ponds, and a similar scenario has been reported elsewhere in Ecuador in $P$. vannamei infected by WSSV. It is interesting that some authors have reported high survival of
P. vannamei, challenged with WSSV, under hyperthermic conditions (Vidal, Granja \& Aranguren 2001; Sonnenholzner, Rodríguez \& Calderón 2002).

Although the histopathology of $P$. vannamei experimentally infected with WSSV has been described in detail by different researchers (Tapay, Lu, Gose, Brock \& Loh1997; Lightner, Hasson, White \& Redman 1998; Nunan, Poulos \& Lightner 
1998), the present study indicates that animals undergoing natural infections under field conditions can present additional histological changes, such as LOS, pyknosis and karyorrhexis. LOS have been reported in penaeids infected by different viruses, including WSSV, although in the latter case not in specific pathogen-free $P$. vannamei experimentally infected with the virus (Owens, de Beer \& Smith 1991; Bonami, Lightner, Redman \& Poulos 1992; Spann, Vickers \& Lester 1995; Lightner 1996; Hasson, Lightner, Mohney, Redman, Poulos \& White 1999a; Vidal et al. 2001) and bacteria (Alday-Sanz, Roque \& Turnbull 2002; Van de Braak, Botterblom, Taverne, Van Muiswinkel, Rombout \& Van der Knaap 2002). Thus, although LOS appear to be strongly associated with WSSV this cannot be unequivocally stated without additional experimental evidence. It appears that the lymphoid organ and the formation of LOS are involved in the immune response of penaeids to infections (Hasson, Lightner, Mohney, Redman \& White 1999b; Anggraeni \& Owens 2000). LOS seem to appear when the animal is able to control the infection or at least to react against it, as in the case of survivors or in chronic infections. Nuclear pyknosis and karyorrhexis have been reported to be associated with several viral infections including yellow head virus (YHV), TSV and lymphoid organ vacuolization virus (Lightner 1996). Nuclear pyknosis and karyorrhexis of the haematopoietic tissue and the lymphoid organ, together with loss of structure, have been considered pathognomic lesions of YHV infection. However, in the samples examined here, these lesions were associated with severe WSSV infection. In Ecuador the presence of YHV has not yet been determined by any technique employed. Pantoja \& Lightner (2003) also observed pyknosis and karyorrhexis in animals experimentally infected with WSSV. In addition, pyknosis and karyorrhexis in haematopoietic tissue have been described in Farfantepenaeus duorarum challenged with WSSV (Wang, White, Redman \& Lightner 1999a).

Ultrastructural transformations (nuclear pyknosis, cytoplasmic vacuolization) observed in dead cells in this study resemble apoptotic changes. In addition, cells with pyknotic nuclei were encapsulated by haemocytes without melanization. Similar modifications have been described in apoptotic events. Apoptosis in WSSV infected shrimp has been reported in Penaeus monodon (Sahtout, Hassan $\&$ Shariff 2001) and P. vannamei (Granja,
Aranguren, Vidal, Aragón \& Salazar 2003). In higher vertebrates apoptosis is a mechanism to eliminate cells infected by virus (O’Brien 1998). The presence of virions in the cytoplasm of cells with pyknotic nuclei (without nuclear replication) suggests a similar mechanism in shrimp.

More studies are required to establish if apoptosis is a mechanism to eliminate viral infection in shrimp, however, there is now some published evidence suggesting that this occurs. Hasson et al. (1999b) reported cellular changes characteristic of apoptotic cells in the lymphoid organ of shrimp which have controlled TSV infection, and Wang et al. (1999a) observed pyknosis and karyorrhexis in animals that survived WSSV induced infections. In addition, Granja et al. (2003) have seen a high degree of apoptosis in shrimp surviving WSSV infections.

Our TEM observations of viral structure and morphogenesis agree with the descriptions of other authors on penaeid shrimp infected by WSSV. The structure we refer to as LRS has been reported in P. vannamei (Durand, Lightner, Redman \& Bonami 1997) and P. monodon (Wang et al. 1999b) infected with WSSV. We observed up to eight longitudinal electron dense bands and four lighter bands in one LRS, as reported by Wang et al. (1999b). Durand et al. (1997) considered this structure as an assembly of nucleocapsid precursors, while Wang et al. (1999b) proposed that 'the LRS may compromise WSSV nucleosomes that are associated with early viral replication'. In our investigation the LRS was present both in the early and late stages of viral replication and assembly. The use of specific antibodies against parts of the WSSV virion such as the nucleocapsid protein VP26 (van Hulten, Westenberg, Goodall \& Vlak 2000) and the immunogold labelling technique could be used to conclusively establish the nature of the LRS.

The occasional presence of two nucleocapsids within one envelope amongst singly enveloped nucleocapsids as observed here has been reported in Fenneropenaeus chinensis infected by WSSV (Zhan et al. 1998), and in the crab, Carcinus maenas (L.), infected by a rod-shaped nuclear virus, although it is considered as a rare occurrence in crabs (Johnson 1988). This occurrence is also uncommon in penaeids infected by WSSV, as it has not been reported in other ultrastructural investigations in P. vannamei (Durand et al. 1997; Tapay, Lu, Gose, Brock \& Loh 1997; Rajendran, 
Vijayan, Santiago \& Krol 1999; Wang et al. 1999a) or other penaeid shrimps (see e.g. Inouye et al. 1994; Takahashi, Itami, Kondo, Maeda, Fujii, Tomonaga, Supamattaya \& Boonyaratpalin 1994; Wongteerasupaya et al. 1995; Wang et al. 1999a,b).

\section{Acknowledgements}

The authors wish to thank the different shrimp farmers who provided access and collaboration during sampling and fieldwork in these studies. The authors also wish to thank Xavier Romero for his advice on the pathological aspects of this paper and July Nieto for English corrections. Dr Claudia Venegas (Universidad de Santiago, Chile) is acknowledged for her comments and suggestions on the original manuscript.

\section{References}

Alday-Sanz V., Roque A. \& Turnbull J.F. (2002) Clearing mechanisms of Vibrio vulnificus biote I in the black tiger shrimp Penaeus monodon. Diseases of Aquatic Organisms 48, 91-99.

Anggraeni M.S. \& Owens L. (2000) The haemocytic origin of lymphoid organ spheroid cells in the penaeid prawn Penaeus monodon. Diseases of Aquatic Organisms 40, 85-92.

Bell T.A. \& Lightner D.V. (1988) A Handbook of Normal Penaeid Shrimp Histology. The World Aquaculture Society, Baton Rouge, LA.

Bonami J.R., Lightner D.V., Redman R.M. \& Poulos B.T. (1992) Partial characterization of a togavirus (LOVV) associated with histopathological changes of the lymphoid organ of penaeid shrimp. Diseases of Aquatic Organisms 14, 145-152.

Calderón J.V., Bayot B., Betancourt I. \& Alday de Graindorge V. (1999) Monitoreo del virus de la mancha blanca en Ecuador. El Mundo Acuicola 5, 211-214.

Cámara Nacional de Acuacultura (2001) Ecuador compite logró un acuerdo de voluntades. Acuacultura del Ecuador 45, 60-63.

Chou H.Y., Huang C.Y., Wang C.H., Chiang H.C. \& Lo C.F. (1995) Pathogenicity of a baculovirus infection causing white spot syndrome in cultured penaeid shrimp in Taiwan. Diseases of Aquatic Organisms 23, 165-173.

Durand S., Lightner D.V., Redman R.M. \& Bonami J.R. (1997) Ultrastructure and morphogenesis of white spot syndrome baculovirus. Diseases of Aquatic Organisms 29, 205-211.

Flegel T.W., Boonyaratpalin S. \& Withyachumnarmkul B. (1997) Progress in research on yellow-head virus and whitespot virus in Thailand. In: Diseases in Asian Aquaculture III (ed. by T.W. Flegel \& I.H. MacRae), pp. 285-295. Asian Fisheries Society, Fish Health Section, Manila, Philippines.

Granja C.B., Aranguren L.F., Vidal O.M., Aragón L. \& Salazar M. (2003) Does hyperthermia increase apoptosis in white spot syndrome virus (WSSV)-infected Litopenaeus vannamei? Diseases of Aquatic Organisms 54, 73-78.

Hasson K.W., Lightner D.V., Mohney L.L., Redman R.M., Poulos B.T. \& White B.M. (1999a) Taura syndrome virus (TSV) development and the disease cycle in the Pacific white shrimp Penaeus vannamei. Diseases of Aquatic Organisms 36, 81-93.

Hasson K.W., Lightner D.V., Mohney L.L., Redman R.M. \& White B.M. (1999b) Role of lymphoid organ spheroids in chronic Taura syndrome virus (TSV) infections in Penaeus vannamei. Diseases of Aquatic Organisms 38, 93-105.

van Hulten M.C.W., Westenberg M., Goodall S.D. \& Vlak J.M. (2000) Identification of two major virion protein genes of white spot syndrome virus of shrimp. Virology 266, 227-236.

Inouye K., Miwa S., Oseko N., Nakano H., Kimura T., Momoyama K. \& Hiraoka M. (1994) Mass mortalities of cultured kuruma shrimp Penaeus japonicus in Japan in 1993: electron microscopic evidence of the causative virus. Fish Pathology 29, 149-158.

Jiménez R., Barniol R., de Barniol L. \& Machuca M. (2000) Periodic occurrence of epithelial necrosis outbreaks in Penaeus vannamei in Ecuador. Diseases of Aquatic Organisms 42, 91-99.

Johnson P.T. (1988) Rod-shaped nuclear viruses of crustaceans: hemocyte-infecting species. Diseases of Aquatic Organisms 5, $111-122$.

Jory D.E. \& Dixon H.M. (1999) Shrimp white spot virus in the western hemisphere. Aquaculture Magazine 25, 83-91.

Lightner D.V. (1996) A Handbook of Shrimp Pathology and Diagnostic Procedures for Diseases of Cultured Penaeid Shrimp. The World Aquaculture Society, Baton Rouge, LA.

Lightner D.V., Hasson K.W., White B.L. \& Redman R.M. (1998) Experimental infection of western hemisphere penaeid shrimp with Asian white spot syndrome virus and Asian yellow head virus. Journal of Aquatic Animal Health 10, 271-281.

Nunan L.M., Poulos B.T. \& Lightner D.V. (1998) The detection of white spot syndrome virus (WSSV) and yellow head virus (YHV) in imported commodity shrimp. Aquaculture 160, 19-30.

O'Brien V. (1998) Viruses and apoptosis. Journal of General Virology 79, 1833-1845.

Owens L., de Beer S. \& Smith J. (1991) Lymphoidal parvoviruslike particles in Australian penaeid prawns. Diseases of Aquatic Organisms 11, 129-134.

Pantoja C.R. \& Lightner D.V. (2003) Similarity between the histopathology of white spot syndrome virus and yellow head syndrome virus and its relevance to diagnosis of YHV disease in the Americas. Aquaculture 218, 47-54.

Rajendran K.V., Vijayan K.K., Santiago T.C. \& Krol R.M. (1999) Experimental host range and histopathology of white spot syndrome virus (WSSV) infection in shrimp, prawns, crabs and lobsters from India. Journal of Fish Diseases 22, 183-191.

Sahtout A.H., Hassan M.D. \& Shariff M. (2001) DNA fragmentation, an indicator of apoptosis, in cultured black tiger shrimp Penaeus monodon. Diseases of Aquatic Organisms 44, 155-159. 
Sonnenholzner S., Rodríguez J. \& Calderón J. (2002) Temperature and WSSV: CENAIM studies promising shrimp culture technique. Global Aquaculture Advocate 5, 55-57.

Spann K.M., Vickers J.E. \& Lester R.J. (1995) Lymphoid organ virus of Penaeus monodon from Australia. Diseases of Aquatic Organisms 23, 127-137.

Takahashi Y., Itami K., Kondo M., Maeda M., Fujii R. Tomonaga S., Supamattaya K. \& Boonyaratpalin S. (1994) Electron microscopic evidence of bacilliform virus infection in kuruma shrimp (Penaeus japonicus). Fish Pathology 29, $121-125$.

Tapay L.M., Lu Y., Gose R.B., Brock J.A. \& Loh P.C. (1997) Infection of white spot baculovirus (WSSV) in two species of penaeid shrimp Penaeus stylirostris (Stimpson) and P. vannamei (Boone). In: Diseases in Asian Aquaculture III (ed. by T.W. Flegel \& I.H. MacRae), pp. 297-302. Asian Fisheries Society, Fish Health Section, Manila, Philippines.

Thrusfield M. (1995) Veterinary Epidemiology. Blackwell Science, Edinburgh.

Van de Braak C.B.T, Botterblom M.H.A., Taverne N., Van Muiswinkel W.B., Rombout J.H.W.M. \& Van der Knaap P.W. (2002) The roles of haemocytes and the lymphoid organ in the clearance of injected Vibrio bacteria in Penaeus vannamei shrimp. Fish and Shellfish Immunology 13, 293-309.

Vidal O.M., Granja C.B. \& Aranguren F. (2001) A profound effect of hyperthermia on survival of Litopenaeus vannamei juveniles infected with white spot syndrome virus. Journal of the World Aquaculture Society 32, 364-372.

Wang Q., White B.L., Redman R.M. \& Lightner D.V. (1999a) Per os challenge of Litopenaeus vannamei post-larvae and Farfantepenaeus duorarum juveniles with six geographic isolates of white spot syndrome virus. Aquaculture 170, 179-194.

Wang Y.G., Hassan M.D., Shariff M., Zamri S.M. \& Chen X. (1999b) Histopathology and cytopathology of white spot syndrome virus (WSSV) in cultured Penaeus monodon from peninsular Malaysia with emphasis on pathogenesis and the mechanism of white spot formation. Diseases of Aquatic Organisms 39, 1-11.

Wongteerasupaya C., Vickers J.E., Sriurairatana S., Nash G.L., Akarajamorn A., Boonsaeng V., Panyim S., Tassanakajon A., Withyachumnarnkul B. \& Flegel T.W. (1995) A nonoccluded systemic baculovirus that occurs in cells of ectodermal and mesodermal origin and causes high mortality in the black tiger prawn Penaeus monodon. Diseases of Aquatic Organisms 21, 69-77.

Zhan W.B., Wang Y.H., Fryer J.L., Yu K.K., Fukuda H. \& Meng Q.X. (1998) White spot syndrome virus infection of cultured shrimp in China. Journal of Aquatic Animal Health 10, 405-410.

Received: 18 September 2002

Accepted: 1 April 2003 